\title{
Evaluation of oxidation techniques for preparing bioassay and environmental samples for liquid scintillation counting
}

Holly H. Miller

\section{MASTER}

October 1979

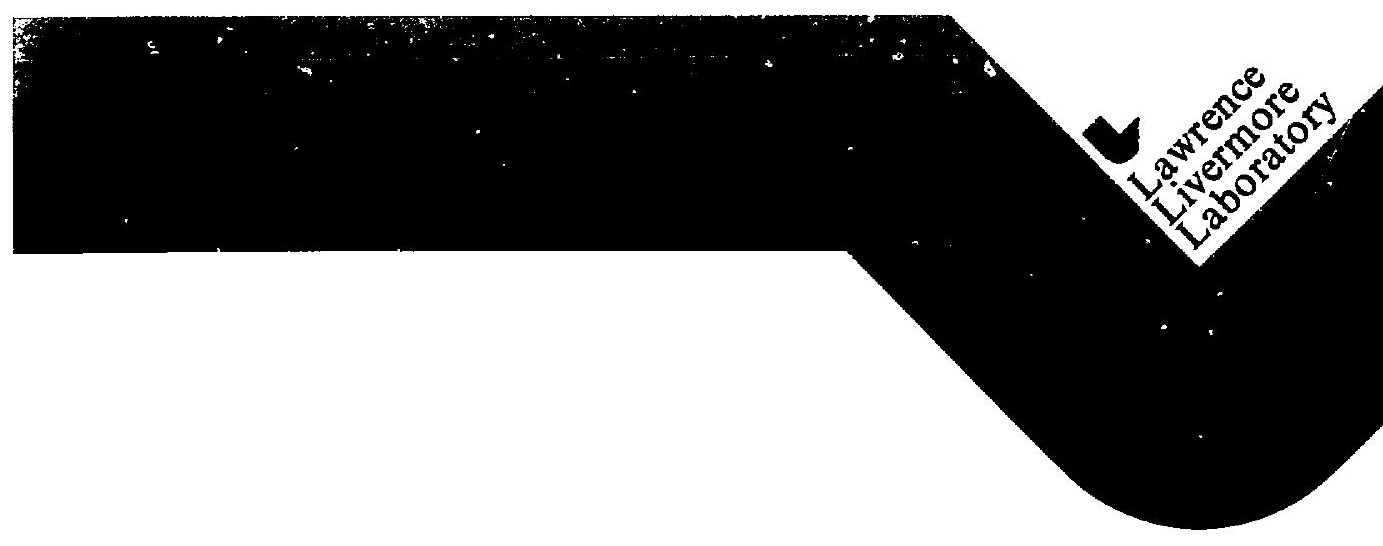


UCRL-52966

Distribution Category UC-11

\title{
Evaluation of oxidation techniques for preparing bioassay and environmental samples for liquid scintillation counting
}

\author{
Holly H. Miller
}

Manuscript date: October 1979

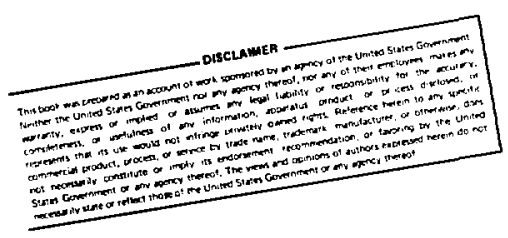

\section{LAWRENCE LIVERMORE LABORATORY} University of California $\bullet$ Livermore, California $\bullet 94550$ 


\section{CONTENIS}

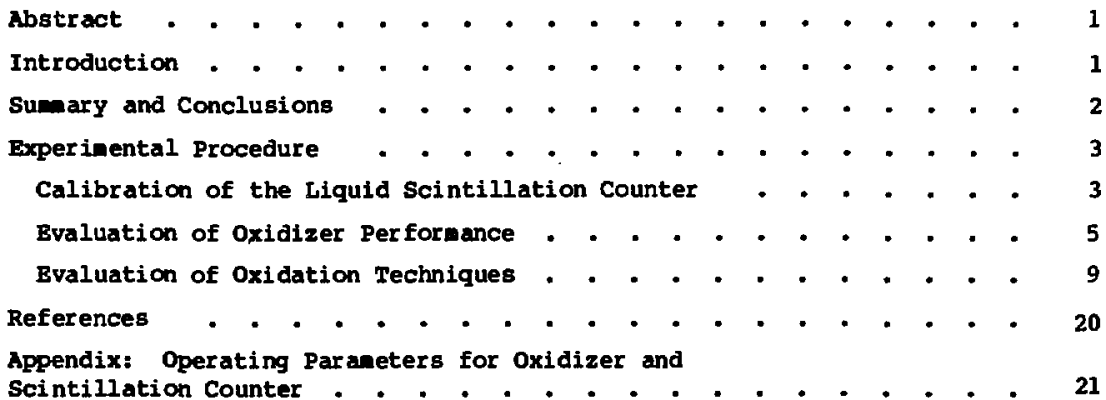


EVALUATION OF OXIDATION TECENIOUES

FOR PREAPARIYG BIOASSAY AND ENVIROMMERTAL SAYPLES

FOR LIOUID SCINTILLATION CONMTIKG

\begin{abstract}
In environmental and biological monitoring for carbon-14 and tritium, the presence of color and chemical quenching agents in the saaples can degrade the efficiency of liquid scintillation counting. A series of experiments was perforned to evaluate the usefulness, under routine conditions, of first oxidizing the samples to ioprove the counting by removing the color and quenching agents. The scintillation counter was calibrated for the effects of quenching agents on its counting efficiency. Oxidzing apparatus was tested for its ability to accurately recover the ${ }^{14} \mathrm{C}$ and ${ }^{3} \mathrm{~B}$ in the samples. Scintillation counting efficiencies were compared for a variety of oxidized and unoxidized environnental and bioassay samples. The overall conclusion was that, for routine counting, oxidation of such sapples is advantageous when they are highly quenched or in solid form.
\end{abstract}

INTRODUCTION

In many, cases, direct application of liquid scintillation counting techniques to biological and environmental samples is inpractical. Mqueous systens are often inmiscible with the organic solvents used in scintillation counting, and high concentrations of color and chenical quench can cause large variations in counting efficiency. Conbustion techniques have proved useful in reducing sapples of diverse origin to carbon dioxide and water, which can be trapped and counted for carbon-14 and tritium, respectively. During the combustion or oxidation of the samples, the quenching agents are effectively rewoved, and the oxidized sanple is automatically dispensed into a counting vial containing highly efficient scintillation solvents unique to the oxidizing apparatus.

To facilitate this technique, various comercial automated conbustion units have been developed. At Lawrence Livermore National Laboratory, the 
Packard Model B-306 Tri-Carb sample oxidizer is used in monitoring the presence of carbon-14 and tritiun in bioassay and environnental samples.

This report describes a series of experiments conducted to evaluate the usefulness of oxidation techniques for preparing bioassay and environental samples for liquid scintillation counting at LLNL. The series consisted of the following parts:

1. Calibrating the liquid scintillation counter for changes in efficiency due to the presence of quenching agents in the sapple.

2. Determining the oxidizer's conformance with the manufacturer's specifications with respect to a) recovery of carbon-14 and tritiun from the original sample and b) residual activity in the system after the processing of a sample.

3. Determining for what kind of samples and by what operating procedures prior oxidation of the samples would significantly inprove the efficiency of liquid scintillation counting.

SUMYARY AND CONCLUSIONS

The data presented in this report reflects that oxidation of the samples results in an overall improvenent in the recovery of tritiug and carbon-14 in bicassay and environmental samples containing high concentrations of color or chemical quench. Although statistics show the recovery of tritium in urine to be enhanced $16 \%$ by oxidation, the large variability of the data, reflected in the standard deviation of \pm 0.25 or $25 \%$, nust be considered before applying this technique to a large volume of routine samples.

In general, urine samples prepared directly without oxidation have greater precision, require 50 less tine to prepace, and have a 40.5 probability of recovering greater than 90 s of the tritiun recovered by oxidation. As would be expected, oxidation of tritius samples which have been predistilled before counting, effectively resoving quenching agents present, does not show improved recovery. Furthernore, sanples which have not been predistilled but nevertheles: contain very little quench also show little or no enhancement of tritium detection using the oxidation nethod of preparation before counting. sone of the data on these samples is incomplete since the channel ratios of the counting data fell below the $r$ ange of the calibration curves. Additional 
curves are being developed over a full range of activities from very low to very high concentrations of tritiun and carbon-14 to enable better interpretation of the experimental ciata.

Oxidation has proved to be a very useful technique when used to prepare solid sanples for tritiu counting, including samples of tissue, tritiuinpregnated plastics, swipes, and tritiun pump oils. Oxidation is recomended for these as well as other special samples of this kind, where the physical state of the sanple would obviously limit the detection of beta activity.

Perfornance tests on the oxidizer for carbon-14 recovery show an average recovery of 31.1 for standards in the range of $0.01 \mu \mathrm{Ci} / \mathrm{liter}, 83.3 \mathrm{t}$ for standards containing $12.5 \mu \mathrm{Ci} / \mathrm{liter}$, and $97.6 \mathrm{t}$ recovery for standards containing $133 \mu \mathrm{Ci} /$ liter. Recovery of tritiun from calibrated standards is also excellent at a value of 98.8 for tritiu activity as $10 \mathrm{w}$ as $1.7 \mu \mathrm{Ci} / \mathrm{liter}$.

In the final enalysis, certiin factors should be considered before applying the oxidation technique to large volues of routine bioassay and environmental sanples. These are: the precision of data, the improvement of counting efficiency, the speed of sanple preparation, the relative recovery of isotopes, and the linits of sensitivity of recovery for each sethod. Based on the data presented in this report, oxidation of bioassay and environmental samples proves to be advantageous only when samples are highly quenched or in solid form.

EXPERIMENTML PROCEDURE

CALIBRATION OF THE LIQUID SCINTILLATION COJNTER

The channels-ratio technique was used to calibrate the liquid scintillation counter for changes in efficiency due to sall anounts of quench still present in the final sample. This technique is based upon the observation that quenching causes attenuation of high-energy pulses and the complete elinination of those pulses barely above the lieit of detection (low-energy pulses). This reaults in a shift in the overall spectrum of pulse heights; see Fig. 1 . The extent of this shift, shown by a change in the channels ratio, indicates a 


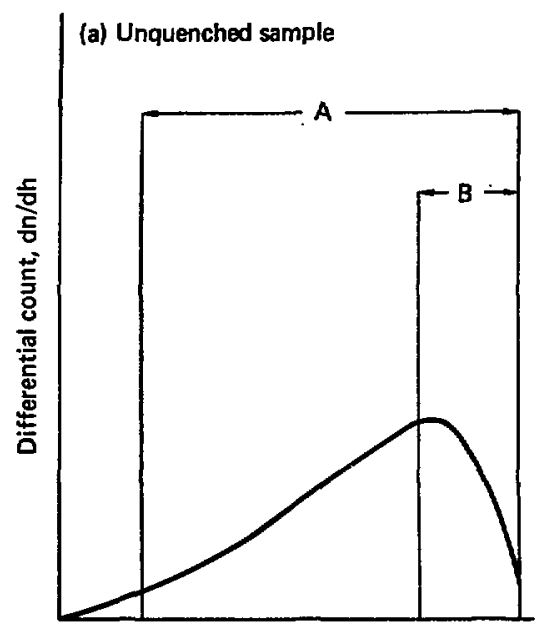

(b) Quenched sample

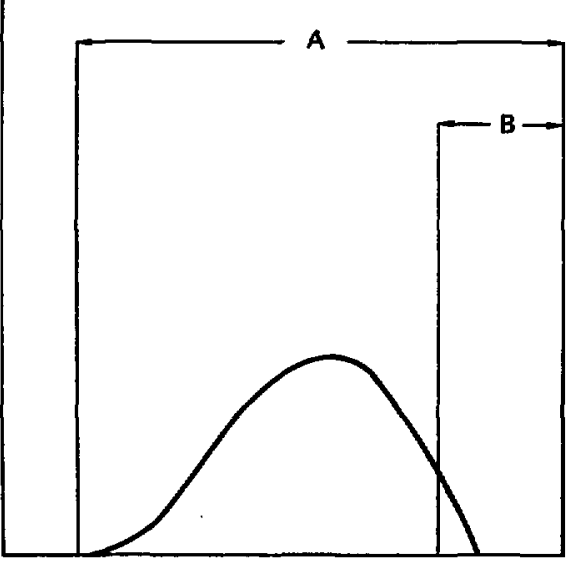

Pulse height, $h$

FIG. 1. The presence of quenching agent in a scintillation-counter sanple will cause a shift in the spectrun of pulse heights, show by a change in the ratio of counts in channels $A$ and $B$.

change in counting efficiency. To do the calibration, a set of standards containing tritiun or carbon-14 are counted, each containing the sane anount of activity, but with increasing anounts of chemical quench. Portions of the unquenched spectrun of pulses are recorded in two separate channels, denoted A and $B$ in Fig. 1. The ratio of counts in channel $A$ to channel $B$ and the corresponding efficiency for each sanple is recorded to produce a quench curve. As the ratios and efficiencies are recorded looking at different portions of the spectrus, a fanily of curves is generated.

Figure 2 shows a fanily of quench curves for carbon-14. The best curve is chosen for its maximum slope and mininu curvature. Figures 3, 4, and 5 are the calibration curves chosen to interpret the counting data for tritiu and carbon-14. The quench curve in Fig. 3 was used to correlate the tritiue oxidation data with the data from duplicate aliquots of tritiun not oxidized. Figures 1 and 5 were used to correlate the carbon-14 data in the sane manner. The scintillation counter settings used in this work are given in the appendix. 


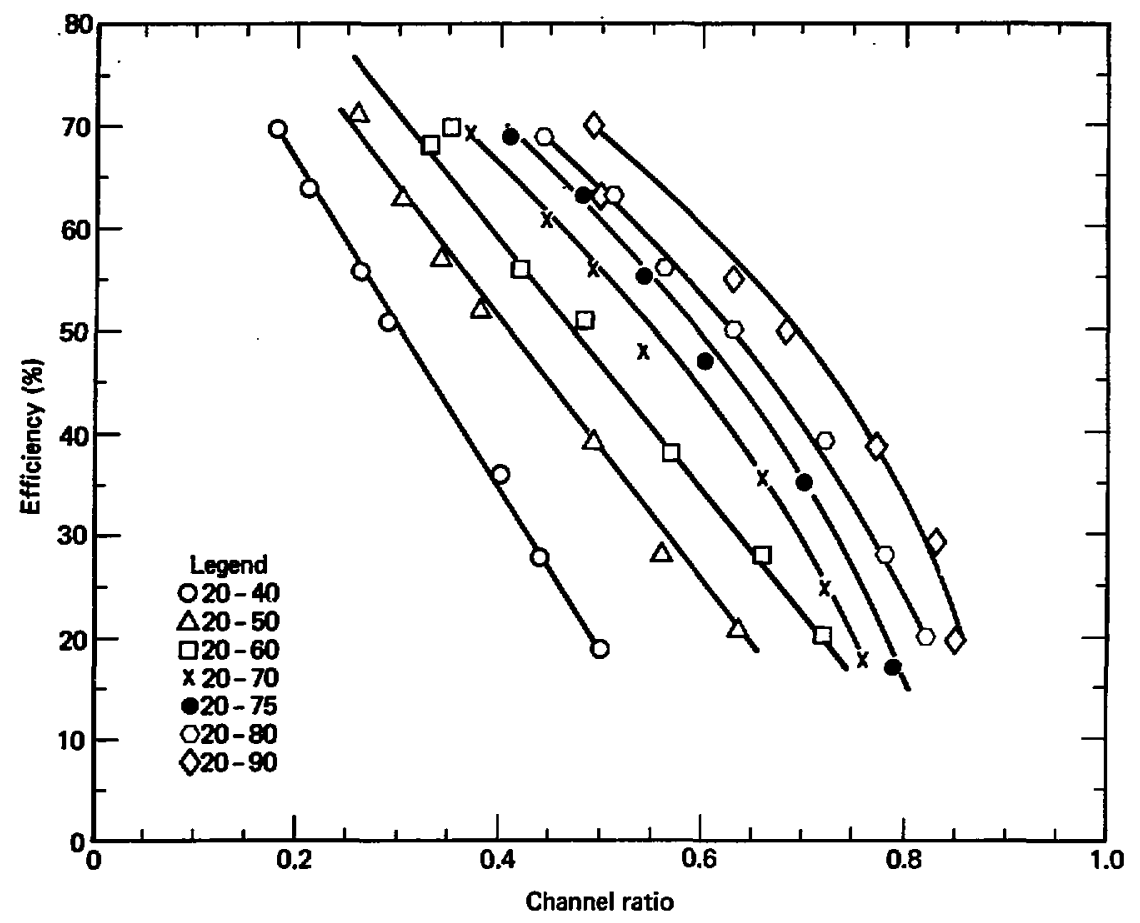

FIG. 2. Quench curve calibration for carbon-14 in oxidizer scintillator. Sample, $0.5 \mathrm{ml}$. Injected activity, $1.4 \times 10^{4} \mathrm{dpm}$. Gain, 208 (both channels). Optimu window settings, $A / B=20-60 / 20-750$.

EVRLUATION OF OXIDIZER PERFORMANCE

In addition to the calibration of :e liquid scintillation counter, performance tests were run to assure that the oxidizer operated within manufacturer's specifications. These specifications state that the recovery of tritiu or carbon-14 from an oxidized sample is $98 \pm 28$. The manufacturer also apecifles that the oxidizer "memory," or degree of residual activity remaining in the equipment after oxidation of these nuclides, is 0.05 (maximum) of the activity present in the oxidized sample. Tables 1 and 2 sumarize the performance data for tritiu and carbon-14. These results indicate good performance for recovery of tritium. In the activity range of $10^{5}$ aisintegrations per 



RIG. 3. Counting efficiency curve for tritiu in oxidizer scintillator. Sample, $0.5 \mathrm{ml}$. Injected activity, $2 \times 10^{3} \mathrm{dpe}$.

FIG. 5. Counting efficiency curve for carbon-14 in oxidizer scintillator. Sample, $0.5 \mathrm{~m}$. Injected activity, $1.4 \times 10^{4} \mathrm{dpm}$.

FIG. 4. Counting efficiency curve or carbon-14 in oxidizer scintillator. Sample, $0.5 \mathrm{ml}$. Injected activity, $1 \times 10^{3} \mathrm{dpm}$.

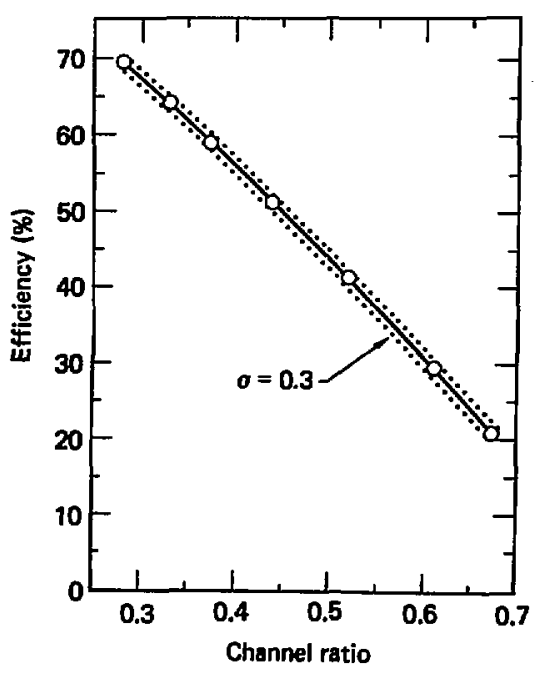


ThBLE 1. Oxidizer performance tests: recovery and mesory of tritium activity.

\begin{tabular}{|c|c|c|c|c|}
\hline \multirow[b]{2}{*}{ Isotope } & \multicolumn{2}{|c|}{ saple activity } & \multirow[b]{2}{*}{ Recovery ( $(z)$} & \multirow[b]{2}{*}{ Menory (s) } \\
\hline & $(\operatorname{dga} / 0.5 \mathrm{el})$ & ( $\mu \mathrm{Ci} /$ liter) & & \\
\hline \multirow{12}{*}{$\begin{array}{l}\text { Tritiu } \\
\text { (Packard } \\
\text { standara) }\end{array}$} & $6.484 \times 10^{5}$ & 584.14 & $98.2 \pm 1.4$ & $0.11 \pm 0.002$ \\
\hline & & & $100.5 \pm 1.4$ & $0.09 \pm 0.002$ \\
\hline & & & $8.2 \pm 1.4$ & $0.08 \pm 0.002$ \\
\hline & . & & $102.1 \pm 1.4$ & $0.00 \pm 0.002$ \\
\hline & & & $99.1 \pm 1.4$ & $0.10 \pm 0.002$ \\
\hline & & & $102.4 \pm 1.4$ & $0.10 \pm 0.002$ \\
\hline & & & $96.9 \pm 1.4$ & $0.10 \pm 0.002$ \\
\hline & & & $97.3 \pm 1.4$ & $0.10 \pm 0.002$ \\
\hline & & & $94.2 \pm 1.4$ & $0.20 \pm 0.002$ \\
\hline & & & $97.8 \pm 1.4$ & $0.24 \pm 0.002$ \\
\hline & & & $97.2 \pm 1.4$ & $0.34 \pm 0.002$ \\
\hline & & & $96.2 \pm 1.4$ & $0.36 \pm 0.002$ \\
\hline \multirow{3}{*}{$\begin{array}{l}\text { Tritiu } \\
\text { (1:500 } \\
\text { standard) }\end{array}$} & $1.909 \times 10^{3}$ & 1.72 & $100.00 \pm 3.41$ & $0.00 \pm 0.001$ \\
\hline & & & $99.30 \pm 3.39$ & $0.00 \pm 0.001$ \\
\hline & & & $97.00 \pm 3.32$ & $0.00 \pm 0.001$ \\
\hline
\end{tabular}

minute (dpa) per 0.5-al sanple, average tritiun recovery is $98.34 \pm 1.40 \%$ with a mewory of 0.154 . For tritiu activities in the range of $10^{3} \mathrm{dpm} / 0.5-\mathrm{ml}$ sample, the average recovered activity measured $98.77 \pm 3.37$ with a menory of 0.008. The performance data on carbon-14 oxidation indicates lower recovery of carbon-14 activity. The average recovery and memory values for carbon-14 listed in Table 2 are: $97.59 \pm 2.08$ recovery and $0.02 \pm 0.0027$ memory for sample activities in the range of $4 \times 10^{5} \mathrm{dpa} / 0.5 \mathrm{ml} ; 83.33 \pm 1.924$ recovery and $0.36 \pm 0.03 *$ mesory for sanple activities in the range of $10^{4} \mathrm{dpm} / 0.5 \mathrm{ml}$; and $24.88 \pm 10.298$ recovery and $0.11 \pm 0.05$ memory for carbon-14 activities in the range of $11.1 \mathrm{dga} / 0.5 \mathrm{ml}$.

steps have been taken to inprove carbon-14 recovery and reduce memory. Resoving the sapple vial on the tritium side of the vial carriage eftar each carbon-14 sanple is oxidized will inprove recovery and reduce menory of the systen. Bince the recovered ${ }^{14} \mathrm{CO}_{2}$ from carbon-14 oxidation must first pass 
TABLE 2. Oxidizer performance tests: recovery and memory of carbon-14.

\begin{tabular}{|c|c|c|c|c|}
\hline \multirow[b]{2}{*}{ Isotope } & \multicolumn{2}{|c|}{ Activity level } & \multirow[b]{2}{*}{ Recovery ( $(*)$} & \multirow[b]{2}{*}{ Memory (z) } \\
\hline & $\left(d_{E m} / 0.5 \mathrm{ml}\right)$ & ( $\mu \mathrm{Cl} / 11$ ter $)$ & & \\
\hline \multirow{4}{*}{$\begin{array}{l}\text { Car bon-14 } \\
\text { (Packard } \\
\text { standard) }\end{array}$} & $4.805 \times 10^{5}$ & 432.88 & $99.80 \pm 2.07$ & $0.03 \pm 0.001$ \\
\hline & & & $100.00 \pm 2.15$ & $0.03 \pm 0.001$ \\
\hline & & & $100.00 \pm 2.15$ & $0.03 \pm 0.001$ \\
\hline & & & $92.92 \pm 2.15$ & $0.01 \pm 0.001$ \\
\hline \multirow[t]{2}{*}{ - } & . & & $94.44 \pm 1.82$ & $0.01 \pm 0.001$ \\
\hline & & & $98.38 \pm 2.41$ & $0.01 \pm 0.001$ \\
\hline \multirow{6}{*}{$\begin{array}{l}\text { Carbon-14 } \\
\text { (atandard A) }\end{array}$} & $1.3875 \times 10^{4}$ & 12.50 & $90.50 \pm 3.51$ & $0.38 \pm 0.03$ \\
\hline & & & $86.38 \pm 1.28$ & $0.38 \pm 0.03$ \\
\hline & & & $83.87 \pm 1.72$ & $0.38 \pm 0.03$ \\
\hline & & . & $84.50 \pm 1.88$ & $0.07 \pm 0.02$ \\
\hline & & & $77.00 \pm 1.55$ & $0.29 \pm 0.02$ \\
\hline & & & $77.70 \pm 1.57$ & $0.66 \pm 0.02$ \\
\hline \multirow[t]{6}{*}{$\begin{array}{l}\text { Carbon-14 } \\
\text { (standard D) }\end{array}$} & 11.1 & 0.01 & $28.50 \pm 11.9$ & $0.00 \pm 0.06$ \\
\hline & & & $27.90 \pm 9.20$ & $0.32 \pm 0.03$ \\
\hline & & & $28.80 \pm 9.12$ & $0.00 \pm 0.06$ \\
\hline & & & $30.00 \pm 12.9$ & $0.00 \pm 0.06$ \\
\hline & & & $23.80 \pm 9.37$ & $0.00 \pm 0.06$ \\
\hline & & & $16.30 \pm 9.27$ & $0.34 \pm 0.03$ \\
\hline
\end{tabular}

through the tritiun vicl on the way to the carbon exchange and reaction coluns, trace levels of carbon-14 activity can hecome trapped in the waste solvent in this vial. If not removed, the activity contained in the waste solvent in the tritiun vi.i can build up and can then contribute to the memory value for the system. In adaition, replacing the tritius vial after each carbon-14 oxidation keeps the volune of was:e solvent in the tritiun vial to a ninimu.

Counting efficiencies for carbon-14, typically 60\%, can be improved $20 \%$ by reducing the volue of Carbosorb dispensed in the sample vial: Typically the reagent settings used for carbon-14 sanples were $15 \mathrm{ml}$ Carbosorb plus $2 \mathrm{ml}$ Permafluor. To deternine the optinu reagent settings, one can prepare several samples of maximu size and do a series of oxidations, reducing the anount of Carbosorb until a drop-off in recovery is observed. At this point, there is 
not enough Carbosorb to trap the $\mathrm{CO}_{2}$ produced in the oxidation of the simple. The Carbosorb volume should be set 1-2 ml higher than that used when the dropoff in recovery occurred. The absorption capacity of Carbosorb is approximately 5.8 millimoles of $\mathrm{CO}_{2}$ per milliliter. If 10 millimoles of $\mathrm{CO}_{2}$ are produced, one should use approximately 3-4 ml of carbosorb. If high counting efficiency is a priority over reagent costs, $10 \mathrm{ml}$ Permafluor can be used in addition to the Carbosorb volume.

When suming the values of recovery and memory, we note that the sim does not always equal 1007; see Tables 1 and 2 . In the case of clean sample oxidation (no pyrolysis), the remaining activity in the equipment is flushed out of the system vith small volumes of water and solvent into the waste bictle. For sanples known to contain activities in the millicurie range, several flushes of the system should be made to reduce the memory or background of the iustrument before oxidizing low-level environmental or bioassay samples. In tine case of sample pyrolysis, the recovery of sample activity is greatly reduced for both tritium and carbon-14; pyrolysis products coat the system, leaving sample activity behind. This problem does not usually increase the nemory because the wash-down normally carries off pyrolysis products. Carbon-14 pyrolysis products especially would not show as increased menory because they are trapped in the tritiu vial before entering the carbon exchange and reaction columns. Therefore, observing a reduction in recovered carbon-14 activity does not necessarily imply increased memory. ${ }^{1}$

Recommended operating paraneters for the oxidizer are given in the Appendix.

EVALUATION OF OXIDATION TECHNIQUES

\section{Enviromental Samples}

In addition to performance tests, a variety of bioassay and environmental samples were oxidized to evaluate the suitability of the oxidation luethod for routine analysis of these samples. It was suspected that the detection of tritiu and carbon-14 in liquid samples which contained little or no chemical or color quench could not be improved using the oxidation technique. The data shown in Table 3 confirms this hypothesis, the system recovering from oxidized " sanples, on the average, only $89.52 \pm 12.48$ of the tritiun activity measured without oxidation. 
TABLs 3. Recovery of calibrated tritiun standard.

\begin{tabular}{|c|c|c|c|c|}
\hline \multicolumn{2}{|c|}{$\frac{\text { Injected activity }}{(\mu \mathrm{Ci} / \mathrm{liter})(\text { dpw/0.5 ml) }}$} & $\begin{array}{c}\text { Counting } \\
\text { effici ency } \\
\text { (t) }\end{array}$ & \multicolumn{2}{|c|}{$\begin{array}{c}\frac{\text { Activity recovered by oxidation }}{\text { Error }} \\
\text { (t) }\end{array}$} \\
\hline $1 . \overline{73}$ & 1920.30 & 36.0 & 85.8 & \pm 11.3 \\
\hline \multirow[t]{5}{*}{ \pm 13} & \pm 19.20 & 36.0 & 88.9 & \pm 11.7 \\
\hline & & 31.5 & 91.0 & \pm 13.6 \\
\hline & & 33.8 & 93.5 & \pm 13.1 \\
\hline & & 31.2 & 90.3 & \pm 13.7 \\
\hline & & 36.0 & 87.6 & \pm 11.5 \\
\hline
\end{tabular}

Certain environmental samples, such as tritium exhaust stack samples and retention tank samples, undergo distillation before an aliquot is taken for liquid scintillation counting. Therefore, all color and chemical quenching agents have already been effectively renoved. Samples of both types were oxidized, and the data in Table 4 shows the measured activity to be greater for those aliquots directly pipetted into Instagel scintillation cocktail than fcr those undergoing oxidation. The ratio $R / R_{0}$ indicates the relative overall efficiency of the two methods, $R$ representing the measured activity using the direct method and $R_{0}$ the measured activity using the oxidation method.

Another environmental sample tested for improved sensitivity using the oxidation method included swipes of tritium-contaninated equipment removed for decratanination and waste disposal. A significant improvement in tritium detection was accomplished by oxidation of swipes. The improvement in some cases was dranatic, where the direct method resulted in detecting only 18 of the activity detected by oxidation. However, this improved sensitivity is in part due to a change in technique in sanple transfer as well as to oxidizing the sample. Duplicate swipes were collected according to routini procedure and placed in a collection vial with $0.5 \mathrm{ml}$ of distilled water. Normally, when the swipe sample is prepared for counting, the swipe is removed and discarded and the water remaining is poured from the collection vial into a counting vial containing Instagel. In the present case, however, the water from one of the duplicate swipes collected for oxidation was transferred using a disposable pipette, providing a nore efficient transfer of the sample. This swipe and the liquid were then both oxidized to produce the results listed in Table 4 . This data shows that oxidation plus the complete transfer of the liquid accompanying the swipe may increase the sensitivity of detection of tritium by 758 . 
TABLE 4. Measured activities for environmental samples using direct and oxidation techniques for sanple preparation.

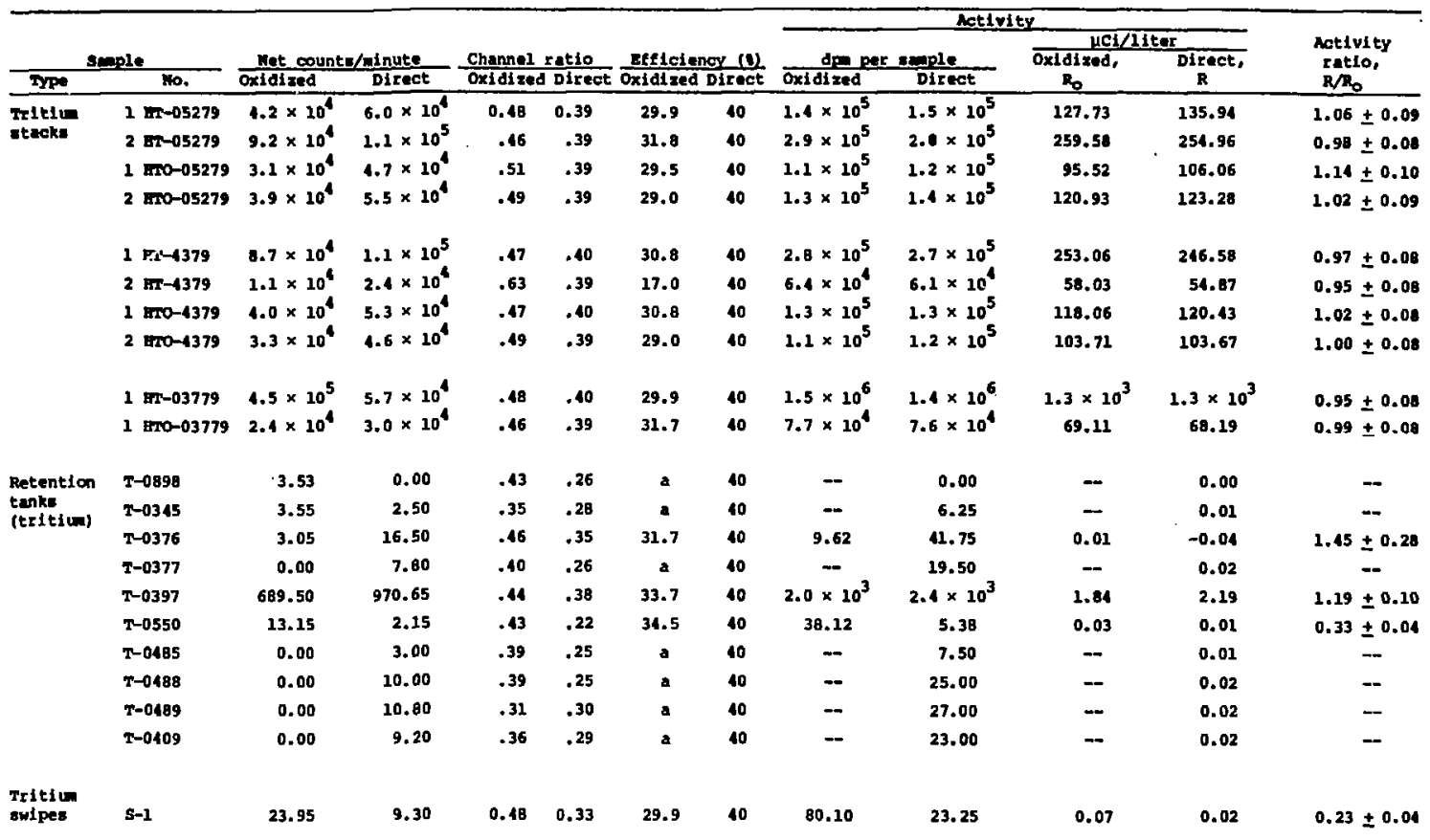


TABLE 4. (Continued.)

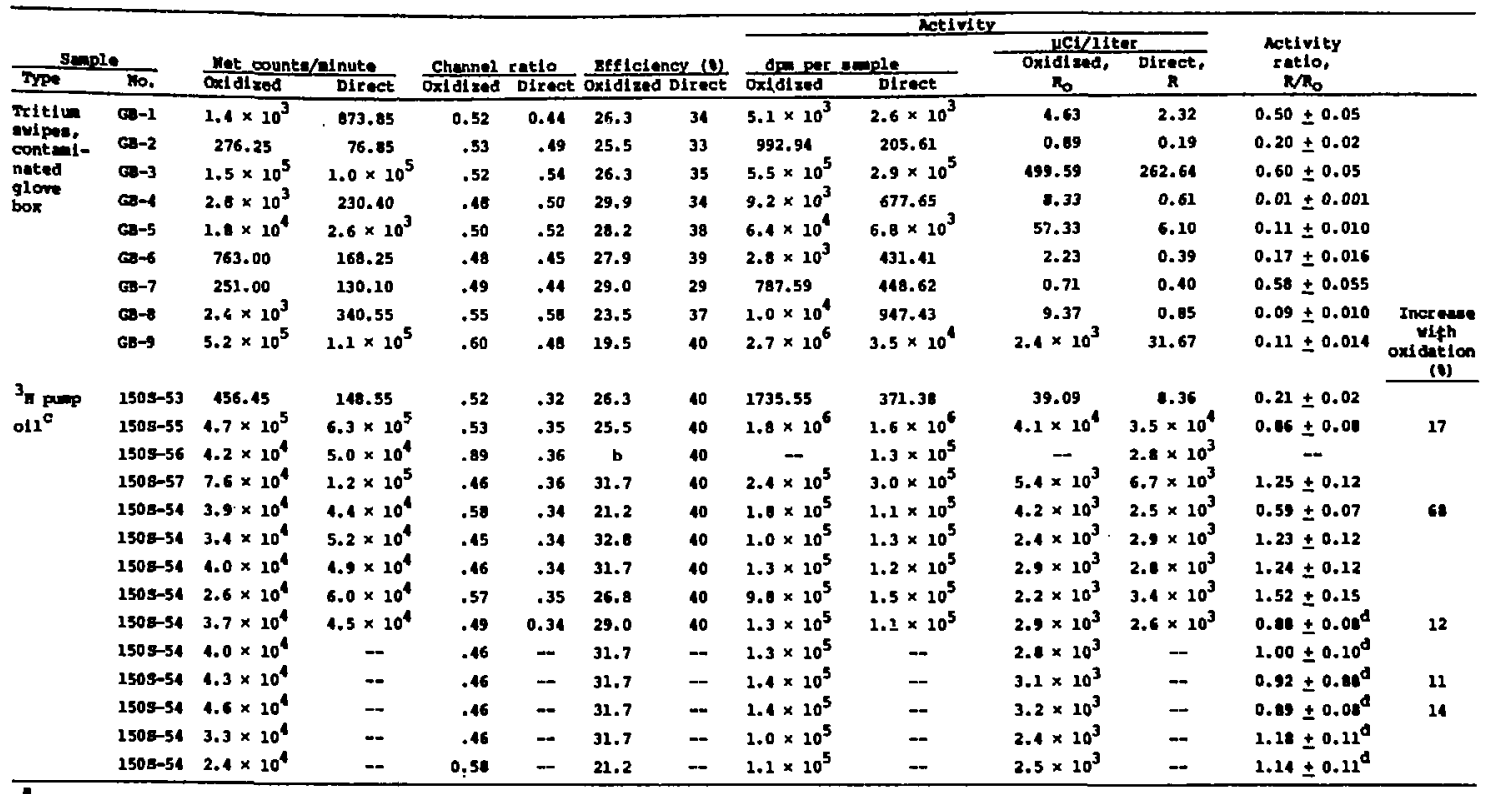

"Channel ratio too low to deteral ne efficiency from quench curve.

bchannel ratio too high to daternime efflalengy from quench curve.

cwo collulose used in oxidution of these eeples.

daverage of $n$ used to deternine ration. 
Tritiu samples of oil from diffusion pumps are also submitted to the counting lab for liquid scintillation counting. These samples are highly quenched and therefore pose a probles to the sensitivity of detection of tritiu. The volume of oil used for direct analysis was limited to $20 \mu \mathrm{l}$ because of the high quenching effect and was kept to $20 \mu l$ for oxidation. Oils are very slow-burning during oxidation. This is because the oxygen available to the syste is not enough to support the burn. ${ }^{1}$ The addition of approximately $100 \mathrm{mg}$ of cellulose powder in addition to 250-500 $\mu \mathrm{l}$ of Combustaid should speed up the burn and help prevent partial combustion. Combustaid, a large-nolecularweight alcohol, helps to wet the cellulose and create a better distribution of the sample for burning. It was added to all oxidized samples. Table 4 shows that for oil samples undergoing complete oxidation without cellulose, an 11 to 68 increase in tritiu detection was observed. However, 7 of the 13 samples oxidized resulted in incomplete combustion, yielding $R / R_{0}$ ratios greater than 1.0; thus the sensitivity of the oxidation method is reduced below that of direct counting. The addition of cellulose powder to the sample inproved the combustion of the sample, and soot was not present in the final sample counted. Studies are in progress to determine the effect of cellulose on counting efficiency.

\section{Bioassay Samples}

Oxidation was also applied to bioassay samples including spinal chord, liver, muscle, and urine. Tissue samples were obtained from the California Primate Research Center at the University of California, Davis, where research on the uptake of tritiun brimates (bonnet and rhesus monkeys) is being studied. Liver, muscle, and spinal chord samples were obtained from the offspring of primates fed tritiated water. Combustion of these samples, using the Packard oxidizer, yielded activities of tritiun that were within 20 of the theoretical values calculated. When counted, 30t of the samples oxidized were within 10 of the level of activity expected, based on the concentration of tritiun in the feed water. ${ }^{2}$ In one case, incomplete conbustion due to inproper burn time resulted in the detection of only 50\%, of the activity expected. In view of the speed and efficiency of the rethod, oxidation is recommended for sanples of this type. 
Urine sanples analyzed for tritiu were obtained from eapioyees routinely monitored for tritiu exposure at LLNL. Duplicate samples collected for bioassay were prepared for counting by the oxidation method and the direct method. Urine sapples analyzed for carbon-14 were collected from unexposed personnel and later spiked with a known activity of carbon-14 standard. The carbon-14 standard was prepared by diluting carbon-14 labelled wethanol with water so as to resenble the biological system.

Figure 6 shows the statistical distribution of the activity ratios R/R for 100 urine samples by both nethods studied. The ratio $R / R_{0}$ was calculated and the probability of the accuracy of specific ratio values was determined to evaluate the use of oxidation for routine preparation of bioassay urine acples. For each urine sanple analyzed, one 0.5-ml aliquot was oxidized with $0.5 \mathrm{ml}$ Combustaid and one 0.5-mil aliquot was pipetted directly into Instagel. The samples were counted and the activity of each was derived using the appropriate quench curve. All associated errors were propagated to the final value of the activity ratio. The average percent error in the value of the ratio

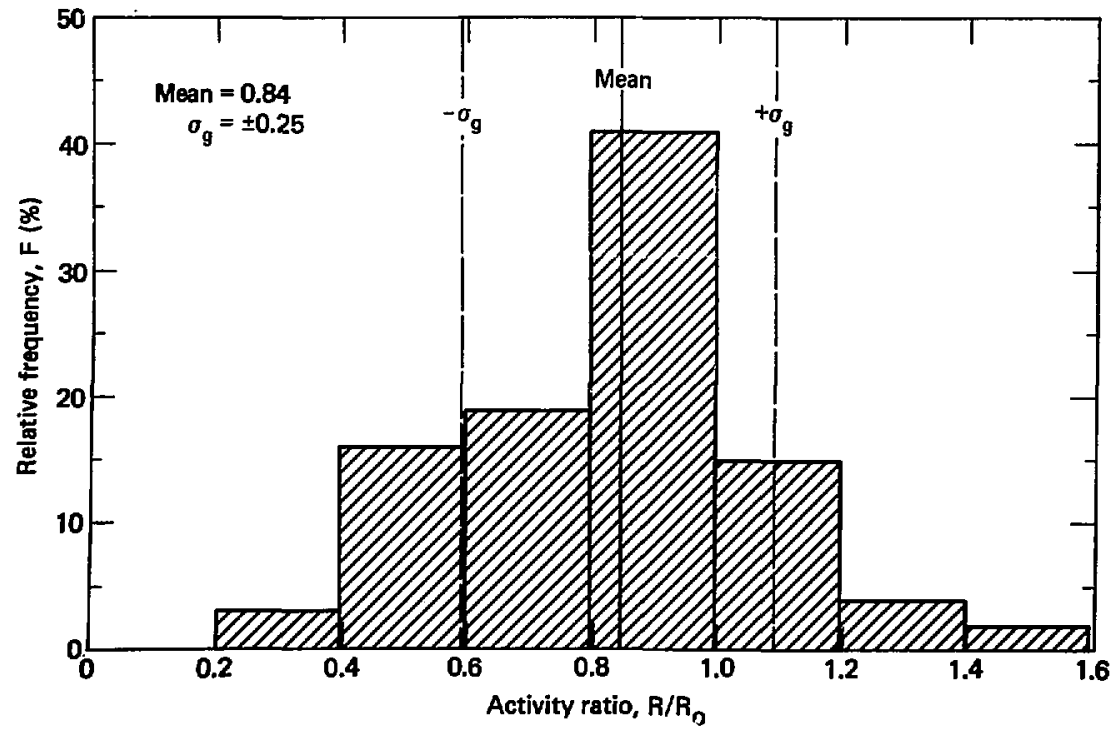

FIG. 6. Frequency of activity ratios for the direct and oxidation methods. nctivity ratio, $R / R_{O}$, is the ratio of tritium activity measured directly (R) to tritiu activity measured after oxidation $\left(R_{0}\right)$. 
itself is 248. Mctivity ratios were grouped and a mean value of $R / R_{0}$ was calculated to be 0.84 with a standard deviation of 0.25 . This means that the direct method of sample preparation is 84 as sensitive as the oxidation nethod, with a fairly large standard deviation of $25 \%$. The relative frequency of the activity ratios for the 100 data points collected is shom in Table 5 and Fig. 6. This data shows that 79 of the samples analyzed had an activity ratio less than 1.0 , indicating some erhancenent of the measurement of tritium by using oxidation for sanple preparation. This data was used to calculate the probability of achieving activity ratios of $0.50,0.80,0.90$, and 0.95 , respectively. Erom the probability statistics shown in Table 6 we know that

TABLE 5. Relative frequency of activity ratios for tritiu in urine (100 data points).

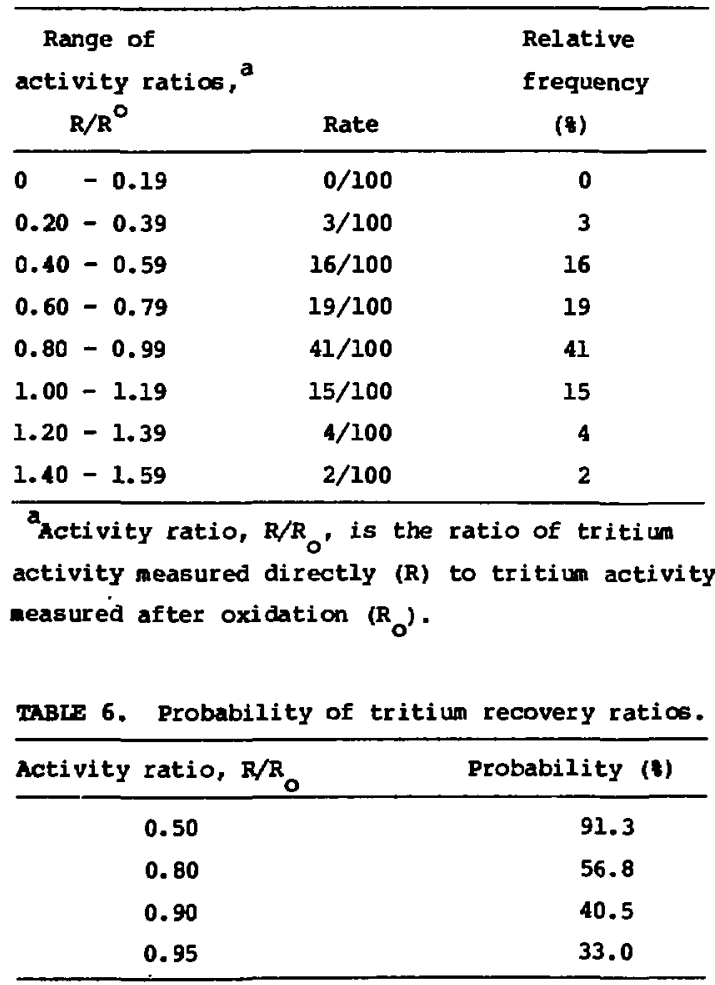


there is a 40.5 probability that the direct method will detect 90 of the tritiva activity present in urine and 334 probsbility that the direct nethod will detect 95 of the tritiv activity in urine.

Five sets of urine standards containing various levels of carbon-14 were analyzed to deternine the liait of sensitivity of both the direct and the oxidation methods. Carbon-14 activities of 0.22 to $2775.0 \mathrm{dp} / 0.5 \mathrm{al}$ urine were studied. Table 7 shows good recovery of carbon-14 in urine for both wethods of sample preparation at activities of $1387.5 \mathrm{dpa} / 0.5 \mathrm{al}$ urine $(1.25 \mathrm{\mu Ci} / \mathrm{liter})$ to $2775.0 \mathrm{~mm} / 0.5 \mathrm{nl}$ urine $(2.50 \mathrm{\mu Ci} / \mathrm{liter})$, with calculated counting efficiencies of 40-80s for oxidized sanples and 70-80s for sanples prepared directly. The channel ratios for sce oxidized samples fell below those on the available quench curve; therefore, new quench curves will be generated covering a wider range of carbor-14 activities to allow retter interpretation of this data. Analysis of urine samples containing $11.1 \mathrm{dpm} / 0.5 \mathrm{ml}$ urine was improved with oxidation. This level of carbon-14 activity in many cases fell below the limit of detection for samples prepared directly. Dropping the carbon-14 activity down to $0.22 \mathrm{dpm} / 0.5 \mathrm{ml}$ urine produced very inconsistent data for both oxidized and directly prepared sanples, and that activity level is considered here to be below the limit of sensitivity for either method. The discrepancies between the counting efficiencies calculated and those derived from the quench curves is a matter open to question, and studies are continuing to resolve the differences. 
TABLE 7. Recovery data of carbon-14 in urine by oxidation.

\begin{tabular}{|c|c|c|c|c|c|c|c|c|c|}
\hline \multirow{2}{*}{$\frac{\text { Injected }}{(\operatorname{den} / 0.5 \mathrm{ml})}$} & \multirow{2}{*}{$\frac{\text { ectivity }}{(\mu \mathrm{ci} / \mathrm{liter})}$} & \multirow{2}{*}{$\begin{array}{c}\text { Sapple } \\
\text { ID }\end{array}$} & \multicolumn{2}{|c|}{ Net counts/nin } & \multicolumn{2}{|c|}{ Channel ratio } & \multicolumn{2}{|c|}{$\begin{array}{l}\text { Calculated counting } \\
\text { efflciency ( }(3)\end{array}$} & \multirow{2}{*}{$\begin{array}{l}\text { Effictency from } \\
\text { guench curve (o) } \\
\text { Direct }\end{array}$} \\
\hline & & & Oxidized & Direct & oxidized & Direct & Oxidized & Direct & \\
\hline 0.22 & 0.0002 & $\begin{array}{l}\text { US3-1 } \\
\text { US3-2 } \\
\text { us3-3 } \\
\text { US3-4 } \\
\text { Us3-5 } \\
\text { US3-6 } \\
\text { US3-7 } \\
\text { us3-8 } \\
\text { us3-9 } \\
\text { us3-10 }\end{array}$ & $\begin{array}{l}0.00 \\
0.00 \\
0.00 \\
0.06 \\
0.34 \\
0.00 \\
0.00 \\
0.00 \\
0.00 \\
0.00\end{array}$ & $\begin{array}{l}0.00 \\
0.00 \\
0.00 \\
0.48 \\
0.46 \\
0.40 \\
0.16 \\
0.00 \\
0.58 \\
0.44\end{array}$ & $\begin{array}{r}0.15 \\
.17 \\
.15 \\
.16 \\
.14 \\
.15 \\
.13 \\
.14 \\
.14 \\
.15\end{array}$ & $\begin{array}{l}0.13 \\
0.14 \\
0.13 \\
0.13 \\
0.13 \\
0.13 \\
0.12 \\
0.12 \\
0.13 \\
0.13\end{array}$ & $\begin{array}{r}0.0 \\
0.0 \\
0.0 \\
27.0 \\
155.0 \\
0.0 \\
0.0 \\
0.0 \\
0.0 \\
0.0\end{array}$ & $\begin{array}{r}0.0 \\
0.0 \\
0.0 \\
218.0 \\
209.0 \\
182.0 \\
73.0 \\
0.0 \\
264.0 \\
200.0\end{array}$ & $\begin{array}{l}60.5 \\
80.1 \\
60.5 \\
60.5 \\
80.5 \\
80.5 \\
81.0 \\
81.0 \\
80.5 \\
80.5\end{array}$ \\
\hline 11.1 & 0.01 & $\begin{array}{l}\text { US4-1 } \\
\text { US4-2 } \\
\text { US4-3 } \\
\text { US4-4 } \\
\text { US4-5 } \\
\text { US4-6 } \\
\text { US4-7 } \\
\text { US4-8 } \\
\text { US4-9 } \\
\text { US4-10 } \\
\text { US4-11 } \\
\text { US4-12 } \\
\text { US4-13 } \\
\text { US4-14 } \\
\text { US4-15 } \\
\text { US4-16 } \\
\text { US4-17 } \\
\text { US4-16 } \\
\text { US4-19 } \\
\text { US4-20 } \\
\text { US4-21 } \\
\text { US4-22 } \\
\text { US4-23 } \\
\text { US4-24 } \\
\text { US4-25 } \\
\text { US4-26 } \\
\text { US4-27 } \\
\text { US4-28 } \\
\text { US4-29 } \\
\text { US4-30 }\end{array}$ & $\begin{array}{r}5.05 \\
4.00 \\
2.45 \\
2.05 \\
2.40 \\
7.05 \\
2.85 \\
0.45 \\
5.50 \\
1.70 \\
9.30 \\
5.70 \\
8.60 \\
7.25 \\
3.25 \\
5.10 \\
11.05 \\
9.10 \\
5.40 \\
8.30 \\
5.50 \\
7.30 \\
4.10 \\
6.05 \\
4.60 \\
7.35 \\
8.60 \\
4.25 \\
7.10 \\
6.30\end{array}$ & $\begin{array}{l}0.00 \\
0.52 \\
0.00 \\
0.07 \\
0.00 \\
1.87 \\
0.00 \\
0.00 \\
0.00 \\
0.72 \\
5.65 \\
1.70 \\
5.45 \\
6.95 \\
5.20 \\
5.40 \\
7.35 \\
5.05 \\
7.45 \\
7.25 \\
- \\
-- \\
-- \\
-- \\
-- \\
-- \\
-- \\
-- \\
-- \\
--\end{array}$ & $\begin{array}{l}.15 \\
.11 \\
.1 \\
.14 \\
.14 \\
.17 \\
.12 \\
.13 \\
.14 \\
.14 \\
.16 \\
.19 \\
.13 \\
.17 \\
.17 \\
.16 \\
.15 \\
.17 \\
.16 \\
.16 \\
.18 \\
.16 \\
.13 \\
.18 \\
.19 \\
.17 \\
.19 \\
.18 \\
.17 \\
0.16\end{array}$ & $\begin{array}{l}0.16 \\
0.12 \\
0.10 \\
0.14 \\
0.12 \\
0.12 \\
0.09 \\
0.13 \\
0.13 \\
0.12 \\
0.08 \\
0.12 \\
0.10 \\
0.07 \\
0.12 \\
0.11 \\
0.12 \\
0.12 \\
0.09 \\
0.11 \\
-- \\
-- \\
-- \\
-- \\
-- \\
-- \\
-- \\
-- \\
-- \\
--\end{array}$ & $\begin{array}{l}45.5 \\
36.0 \\
22.1 \\
18.5 \\
21.6 \\
63.5 \\
25.7 \\
4.1 \\
49.5 \\
15.3 \\
83.8 \\
51.4 \\
77.0 \\
65.3 \\
29.3 \\
45.9 \\
99.5 \\
82.0 \\
48.6 \\
74.8 \\
49.5 \\
65.8 \\
36.9 \\
54.5 \\
41.4 \\
66.2 \\
77.5 \\
38.3 \\
64.0 \\
56.8\end{array}$ & $\begin{array}{r}0.0 \\
4.7 \\
0.0 \\
0.6 \\
0.0 \\
16.8 \\
0.0 \\
0.0 \\
0.0 \\
6.5 \\
50.9 \\
12.3 \\
49.1 \\
62.6 \\
46.8 \\
48.6 \\
66.2 \\
45.5 \\
67.1 \\
65.3 \\
- \\
-- \\
-- \\
-- \\
-- \\
-- \\
-- \\
-- \\
--\end{array}$ & $\begin{array}{l}78.8 \\
81.0 \\
81.3 \\
80.1 \\
81.0 \\
81.0 \\
80.9 \\
80.5 \\
80.5 \\
81.0 \\
80.5 \\
81.0 \\
81.3 \\
79.5 \\
81.0 \\
81.3 \\
81.0 \\
81.0 \\
80.9 \\
80.0 \\
-- \\
-- \\
-- \\
-- \\
-- \\
-- \\
-- \\
-- \\
-- \\
--\end{array}$ \\
\hline
\end{tabular}


TABLE 7. (Continued.)

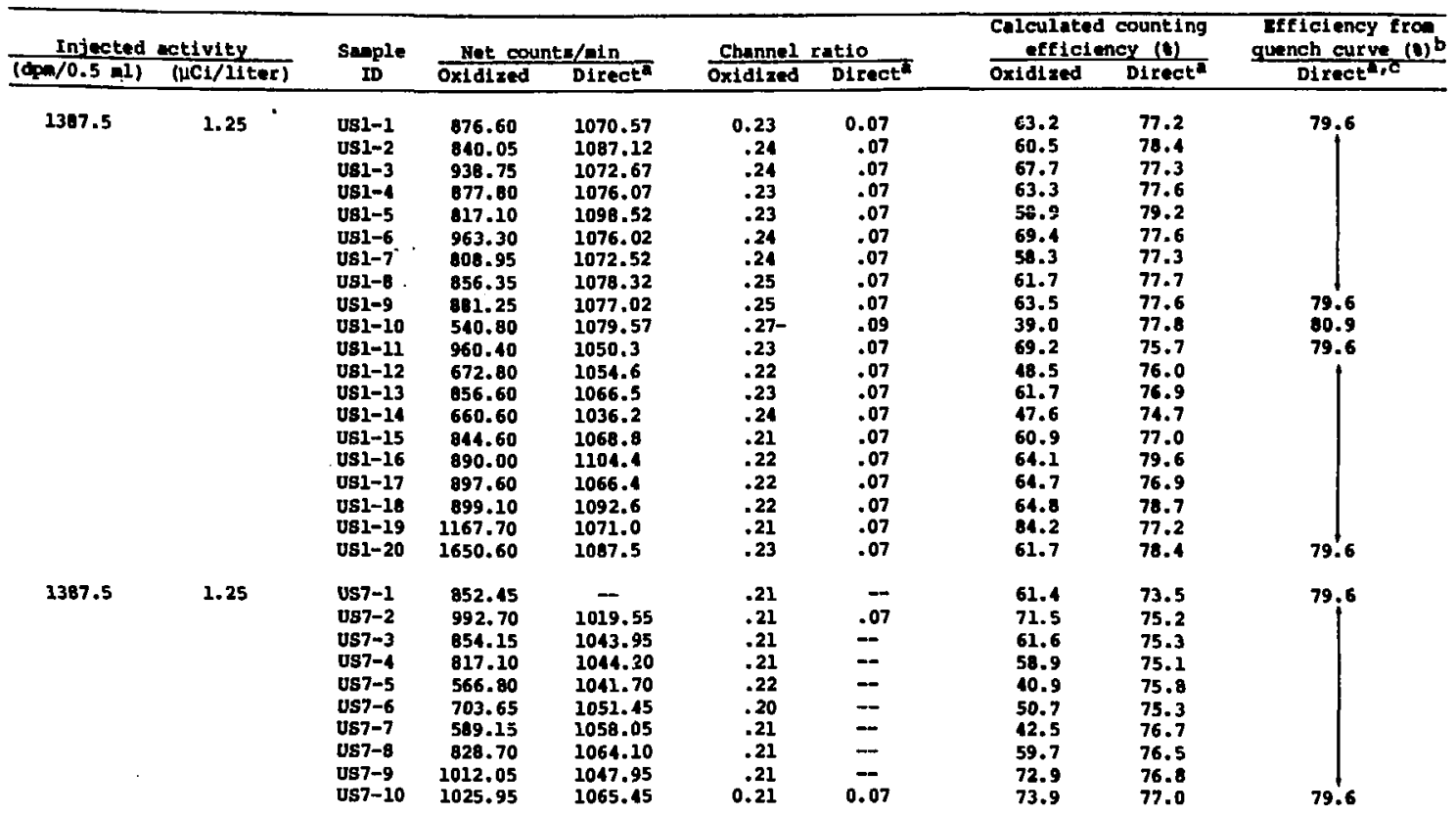


TABLE 7. (Continued.)

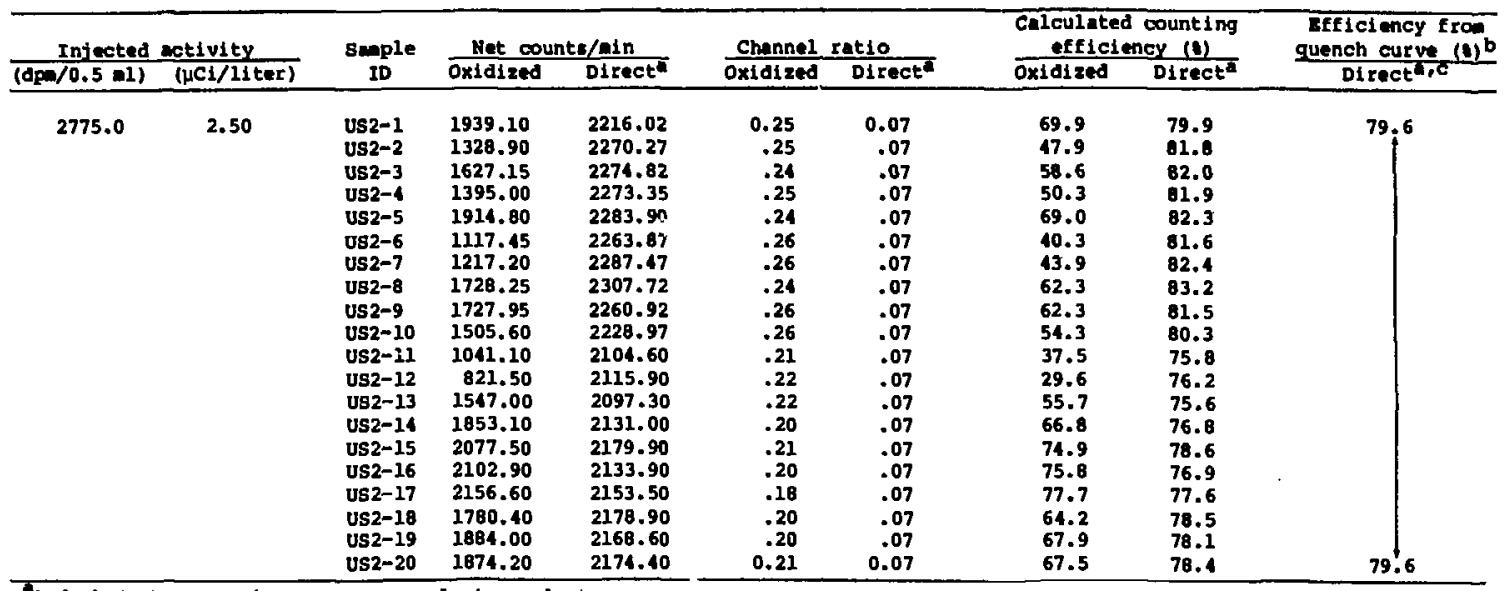

A dash (--) neans there was no sample to evaluate.
bvery entry in the efficiency column has an associated error of \pm 4.16 .

Channel ratio for oxidized samples was too low to deternine efficiency from quench curve. Efficiency eatimated to be 70 . 
1. J. I. Nibeck, Packard Instrument Company, Chicago, IL (1979).

2. M. S. Singh, Lawrence Livernore National Laboratory, Livernore, Ch (1978). 
APPENDIX:

OFERATHYE PARHMETERS FCR OXIDIZER AND SCINTILLATION COUNTER

Oxidizer paraneters for combustion of samples.

\begin{tabular}{|c|c|c|c|}
\hline Type of sanple & Volwe of sample oxidized & $\begin{array}{l}\text { Scintillator } \\
\text { settings }\end{array}$ & $\begin{array}{l}\text { Burn tine } \\
\text { (minutes) }\end{array}$ \\
\hline \multicolumn{4}{|l|}{ Tritiu } \\
\hline $\begin{array}{l}\text { Drine and other } \\
\text { liquids }\end{array}$ & $\begin{array}{l}0.5 \text { l liquid } \\
+0.5 \text { m Combustaid }\end{array}$ & $15 \mathrm{ml}$ Monophase & 1.0 \\
\hline Tissue & $\begin{array}{l}0.5 \mathrm{~g} \text { sample } \\
+0.5 \text { al Conbustaid }\end{array}$ & 15 al Monophase & 2.5 \\
\hline Rubber gaskets & $\begin{array}{l}0.05 \mathrm{~g} \text { sanple } \\
+0.5 \text { l Conbustaid }\end{array}$ & 15 ml Monophase & 1.5 \\
\hline Plastic fibers & $\begin{array}{l}\text { Microgran quantities }(\sim 700) \\
+0.5 \text { al combustaid }\end{array}$ & $15 \mathrm{ml}$ Monophase & 2.0 \\
\hline \multicolumn{4}{|l|}{ Carbon-14 } \\
\hline $\begin{array}{l}\text { Urine and other } \\
\text { liquids }\end{array}$ & $\begin{array}{l}0.5 \text { l liquid } \\
+0.5 \text { C Combustaid }\end{array}$ & $\begin{array}{l}10 \mathrm{ml} \text { Carbosorb } \\
12 \mathrm{ml} \text { Permafluor }\end{array}$ & 1.0 \\
\hline
\end{tabular}

Suggestions:

- Folloi specifications on oxidizer naintenance closely.

- Check gaskets and gas feed systems periodically for leaks.

- Run perfornance checks periodically to monitor the performance of the oxidizer *

- Rinse the vial carriage with methanol after each burn.

- Nlways flush out the oxidizer system after oxidizing samples of high activity to reduce background. To flush: push the program button and run through the cycle with no sample. 
Suggested settings for the Tri-Carb liquid scintillation counter.

\begin{tabular}{|c|c|c|}
\hline \multirow{5}{*}{ Tritiu } & wi ndow $\mathrm{A}-\mathrm{B}$ & $20-120$ \\
\hline & Tindow $C-D$ & $20-560$ \\
\hline & Gain & \\
\hline & Channel $A-B$ & $50 \%$ \\
\hline & Channel C-D & 528 \\
\hline \multicolumn{3}{|c|}{ Carbon-14 } \\
\hline & Window A-B & $20-60$ \\
\hline & Window $C-D$ & $20-750$ \\
\hline & Gain (both channels) & 508 \\
\hline
\end{tabular}

The efficiency-vs-gain curve for carbon- 1.4 is shown in Fig. Al, and the calibration quench curve for carbon-14 in oxidizer scintillator at the optimum gain of 50 is shown in Fig. A2.



FIG. Al. Efficiency vs gain for carbon-14. Calibration made with MeOH-14C. Sample, $0.5 \mathrm{al}$. Injected activity, $1.4 \times 10^{4} \mathrm{dpm}$. Window settings, 20-60/ 20-750. 


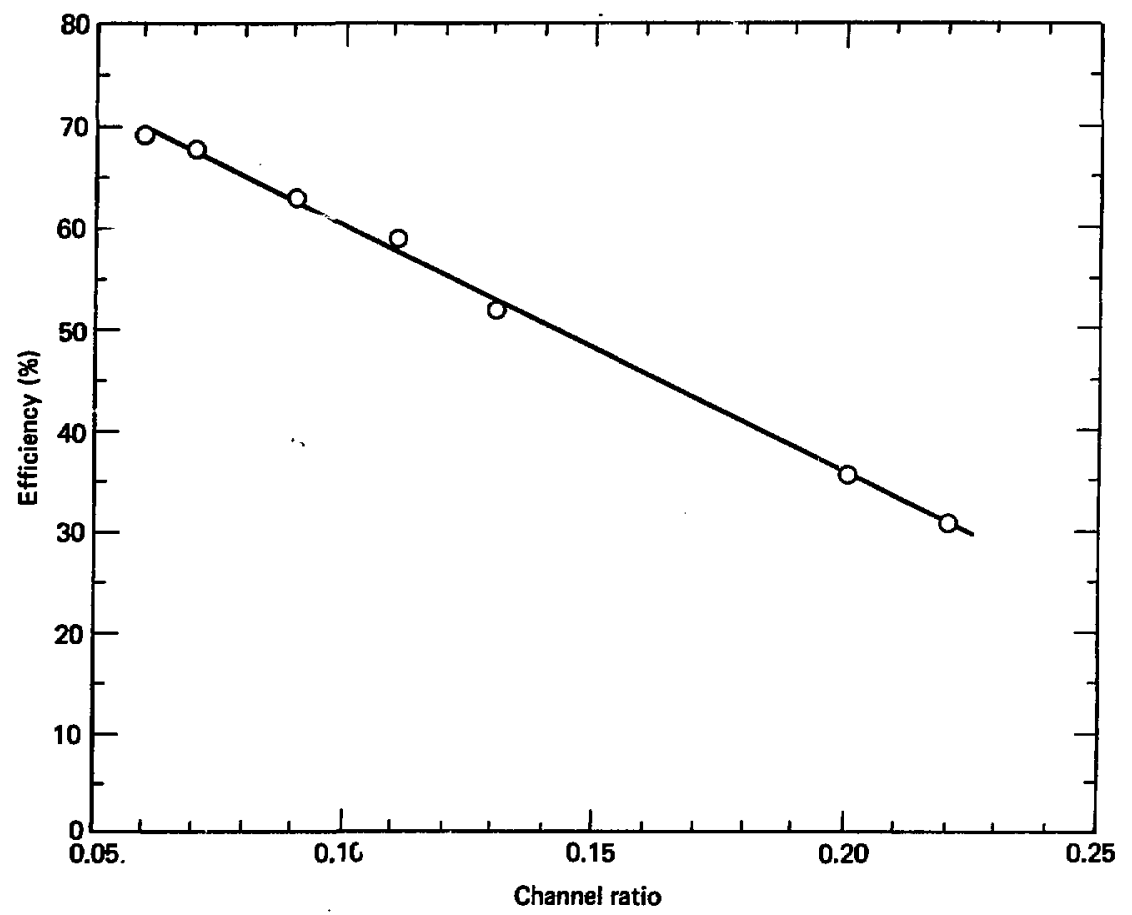

FIG. A2. Optimu carbon-14 quench curve in oxidizer scintillator. Sample, $0.5 \mathrm{ml}$. Injected activity, $1 \times 10^{3} \mathrm{dpm}$. Gain, 508. Window settings, 20-60/ 20-750. 